\title{
Korelasi Persebaran Genta Perunggu Dan Candi Di Propinsi Jawa Tengah
}

\author{
Yuniarso K. Adi
}

Keywords: distribution, metallurgy, bronze, Hindu-Buddhist remains, religion

\section{How to Cite:}

Adi, Y. K. Korelasi Persebaran Genta Perunggu Dan Candi Di Propinsi Jawa Tengah. Berkala Arkeologi, 15(3), 218-226. https:// doi.org/10.30883/jba.v15i3.698
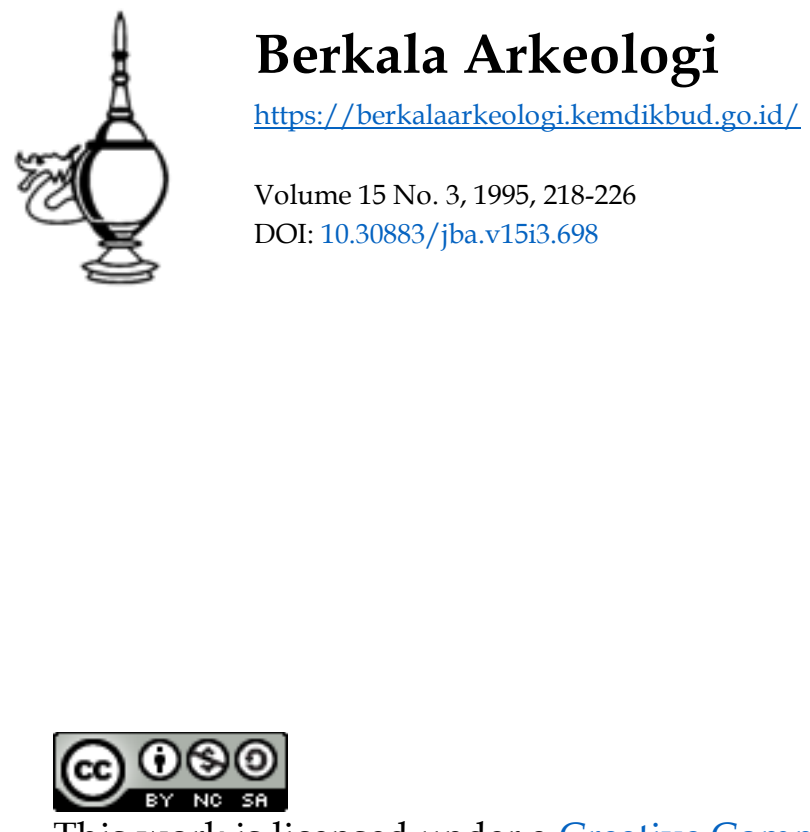

This work is licensed under a Creative Commons Attribution-NonCommercialShareAlike 4.0 International License. 


\title{
KORELASI PERSEBARAN GENTA PERUNGGU DAN CANDI DI PROPINSI JAWA TENGAH
}

\author{
Yuniarso K. Adi \\ (Museum Negeri "Ronggowarsito" Jawa Tengahy
}

\section{।}

Genta dalam bahasa Sansekerta Ghanta bermakna bel atau lonceng. Bahan dasar pembuatan genta adalah logam perunggu. Benda ini berkembang dan dipergunakan oleh masyarakat Hindu-Budha. Macam genta yang diketemukan di Indonesia a.l: a. Genta Gantung, b. genta Pendeta, c. Genta Binatang, dan d. Klintingan (Endang Sri HS;1981). Dari bermacam-macam temuan genta tersebut difungsikan sesuai dengan ma-cam dan bentuknya. Berikut akan dijelaskan mengenai macam-macam genta.

\section{a. Genta Gantung}

Genta gantung adalah genta menyerupai stupa, kemuncak, namun kadang-kadang dikombinasi dengan patung binatang. Dinamakan gen-ta gantung karena pada bagian puncak terdapat rantai untuk menggantungkan genta ini. Pada ukuran kecil, genta berfungsi sebagai alat musik.

\section{b. Genta Pendeta}

Genta ini tidak berantai dan pada bagian puncak terdapat Vajra, Cakra atau sebuah patung. Dinamakan genta pendeta karena biasa dipergunakan oleh pendeta dalam kegiatan upacara keagamaan. Genta pendeta bertangkai Vajra merupakan aspek dualisme dalam kosmos. Genta sebagai simbol feminin sedangkan vajra sebagai simbol maskulin (IGN Anom;1971).

\section{c. Genta Binatang}

Genta ini dari depan berbentuk seperti peng. garon sedangkan dari samping berbentuk pipih. Lubangnya berbentuk bulat telur dan pada kedua ujungnya lancip. Lubang atas berbentuk bulat pipih untuk mengikatkan genta. Biasanya genta ini dipasang pada leher binatang peliharaan.

\section{d. Klintingan}

Jenis genta ini merupakan genta yang tertutup pada bagian bawahnya serta berbandul didalamnya.

Persebaran temuan genta di Propinsi Jawa Tengah sangat luas baik di daerah pedalaman maupun daerah pesisiran dari perbatasan Jawa Tengah dengan Jawa Barat hingga daerah per- batasan Jawa Tengah dengan Jawa Timur. Secara rinci terdapat 32 buah temuan genta dari 9 kabupaten/kotamadia dengan pembagian 4 kabupaten pedalaman dan 5 kabupaten pesisir. Populasi temuan terbanyak adalah genta binatang berjumlah 15 buah, kemudian berturut-turut genta pendeta 11 buah, genta gantung 5 buah dan klintingan 1 buah. Jumlah temuan terbanyak terdapat dipesisiran berjumlah 20 buah, sedangkan di pedalaman 12 buah (lihat lampiran tabel).

Menarik perhatian temuan genta dari pesisiran sejumlah 20 buah tersebut sebagian besar jenis genta pendeta berjumlah 9 buah, 8 buah genta binatang, 2 buah genta gantung dan 1 Klıntingan. Sedangkan didaerah pedalaman temuannya berupa genta pendeta 2 buah dan genta $b$. natang 7 buah serta genta gantung 3 buah.

Jika dikorelasikan dengan persebaran cand Hindu-Budha di propinsi Jawa Tengah nampak ada suatu pertentangan. Genta pendeta yang merupakan alat upacara keagamaan masyarakat Hindu Budha lebih banyak diketemukan di daerah pesisir bukan di daerah pedalaman (hanya 2 (dua) buah saja) sedangkan candi-candi yang merupakan tempat kegiatan keagamaan yang dipimpin oleh seorang pendeta dengan membawa genta di tangan kiri, di Jawa Tengah pada umumnya banyak terdapat di daerah pedalaman (Jawa Tengah Selatan). Candi yang terdapat di Jaeran utara antara lain: Dieng. Gedong songc Cand Kangkung (Kendal), dan situs Bae (Kudus). Sedangkan Candi Dieng serta Gedongsongo itupun terdapat didaerah pedalaman (daerah pegunung. an) bukan pesisir, sehingga hanya ada dua bangunan keagamaan Hindu-Budha di pesisiran yaitu Candi Kangkung dan situs Bae yang keduanya terbuat dari bahan batu bata. Jika dibandingkan dengan bangunan-bangunan candi di daerah pedalaman sangat tidak sebanding sebab populasi temuan candinya sangat banyak antara lain: Candi Borobudur, Mendut, Gunung Wukir, Pendem, Lumbung, Pawon, Sukuh, dan Plaosan. Data ini tentunya menarik perhatian kita. Apakah jenis genta pendeta memang belum diketemukan (sebenarnya banyak)? ataukah upacara keagamaan di daerah pedalaman kurang begitu membutuhkan genta sebagai alat kelengkapannya?

Genta pendeta sebagai kelengkapan kegiatan upacara keagamaan masyarakat Hindu-Buona 
secara logika tentunya akan lebih banyak diketemukan didaerah pedalaman dibandingkan daerah pesisir. Sebaliknya genta binatang yang berfungsi profan lebih banyak diketemukan di daerah pesisir dibandingkan daerah pedalaman, jika dikorelasikan dengan persebaran bangunan candi. Temuan yang ada, menunjukkan persebaran genta pendeta dan genta binatang di daerah pesisir lebih banyak dibandingkan dengan temuan di daerah pedalaman. Perbandingannya 2 buah genta pendeta di pedalaman dan 9 buah di pesisiran; 7 buah genta binatang di pedalaman, 8 buah di pesisiran; 3 buah genta gantung di pedalaman 2 buah di pesisir, sedangkan temuan klintingan hanya ditemukan di pesisir, di pedalaman klintingan tidak ditemukan.

\section{II}

Paparan data di atas menimbulkan permasalahan yang tentunya menarik untuk dibahas ka-

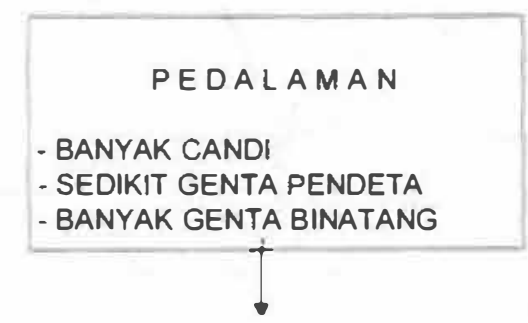

\section{- ADA KEGIATAN RITUAL \\ - GENTA PENDETA KURANG BERPERAN DALAM KEGIATAN RITUAL \\ - UPACARA RITUAL DI CANDI \\ - GENTA BINATANG POPULER \\ DIGUNAKAN MASYARAKAT}

Analogi diatas masih perlu dikaji ulang karena variabel-variabelnya masih perlu dikembangkan dan ditambah. Sebagai informasi data awal perlu menjadi perhatian para peneliti tentang bagaimana bentuk dan tata cara upacara ritual masyarakat Hindu-Budha masa lalu. Besar kemungkinan perkembangan pada masa sekarang ini berbeda dengan masa lalu.

\section{KEPUSTAKAAN}

Endang Sri Hardiati S,1981. Benda-benda Perunggu Koleksi Puslitarkenas. Jakarta

I Gusti Ngurah Anom,1971. Fungsi Genta Pendeta di Bali. Yogyakarta.

Knauth, Percy, 1974. The Metalsmiths rena terdapat korelasi langsung antara populasi persebaran bangunan candi dengan persebaran genta pendeta. Sesuai dengan fungsi utama bangunan candi sebagai tempat kegiatan upacara keagamaan Hindu-Budha (Soekmono; 1974) tentu segala kegiatannya ditunjang dengan peralatanperalatan upacara termasuk salah satunya genta. Dalam melaksanakan kewajibannya pendeta senantiasa memegang genta ditangan kiri, sedangkan tangan kanan memegang alat-alat upacara lainnya atau bunga silih berganti. Sementara pendeta merapalkan weda mantra dengan diiringi bunyi genta yang berhenti pada waktu melakukan mudra. Dapat dikatakan bahwa suara genta adalah suatu pertanda hadirnya seorang pendeta (IGN Anom;1971). Dengan demikian keberadaar: genta tidak dapat terpisahkan dari suatu upacara ritual keagamaan.

Dibawah ini dapat dilihat melalui tabel korelasi antara banyaknya candi dengan banyaknya temuan genta.

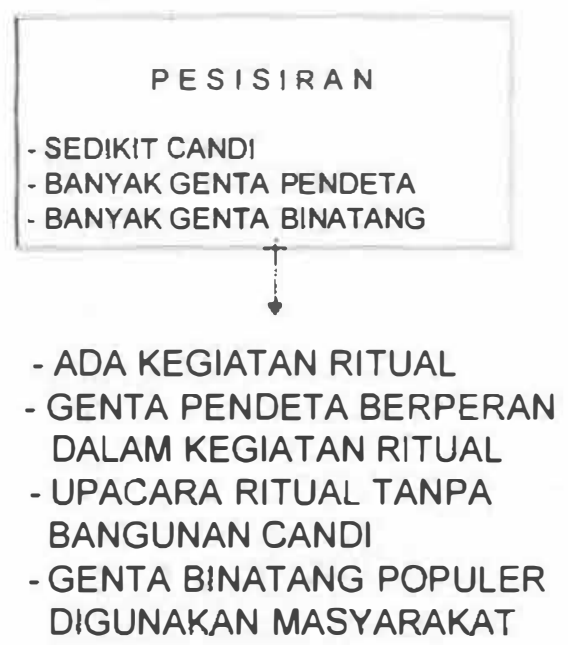

Soekmono, 1974. Candi, Fungsi dan Pengertiannya Disertasi Gurubesar UI 1974

Soetarno, 1991.Aneka Candi Kuno di Indonesia. Dahara. Prize Semarang. 
PETA PERSEBARAN CANDI DAN TEMLAAN GENTA

DI IVII,AYAH PKOVINSI JAWA TENGAH

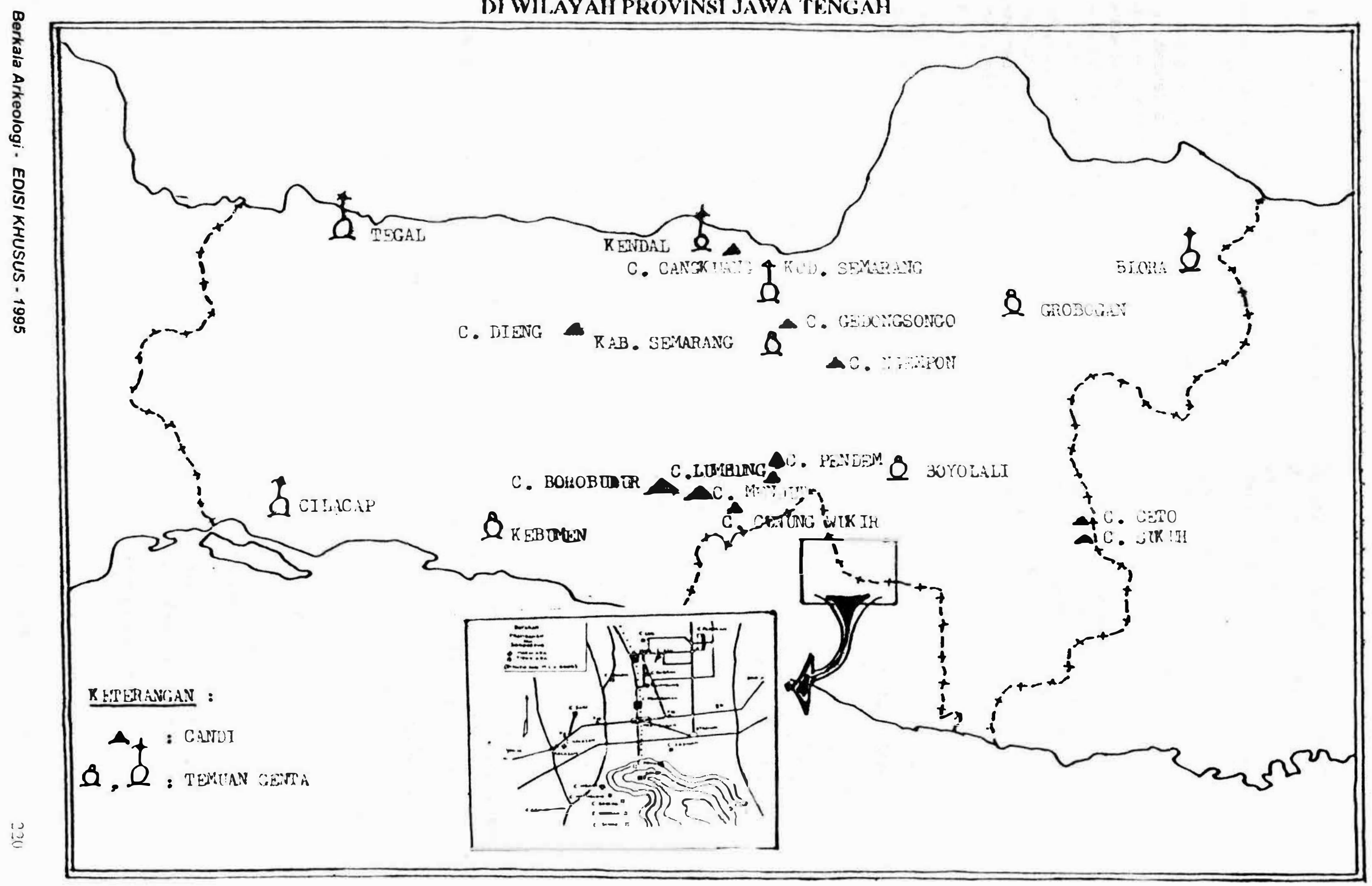


TABEL PERSEBARAN GENTA

PER KABUPATEN DI PROPINSI JAWA TENGAH

TAHUN 1993 / 1994

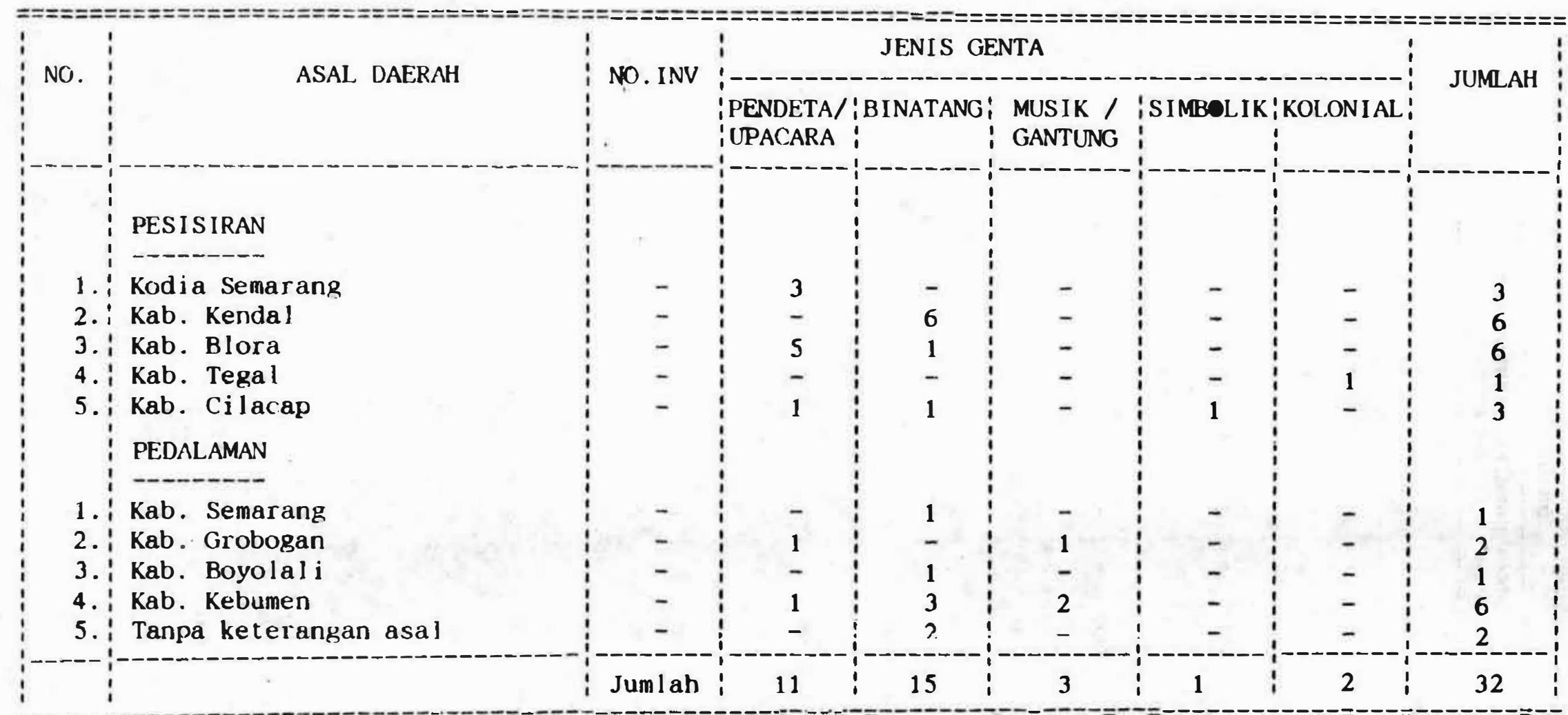

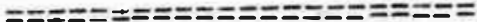

TABEL PERSEBARAN GENTA

MENURUT LETAK GEOCRAFIS

TAHUN $1993 / 1994$

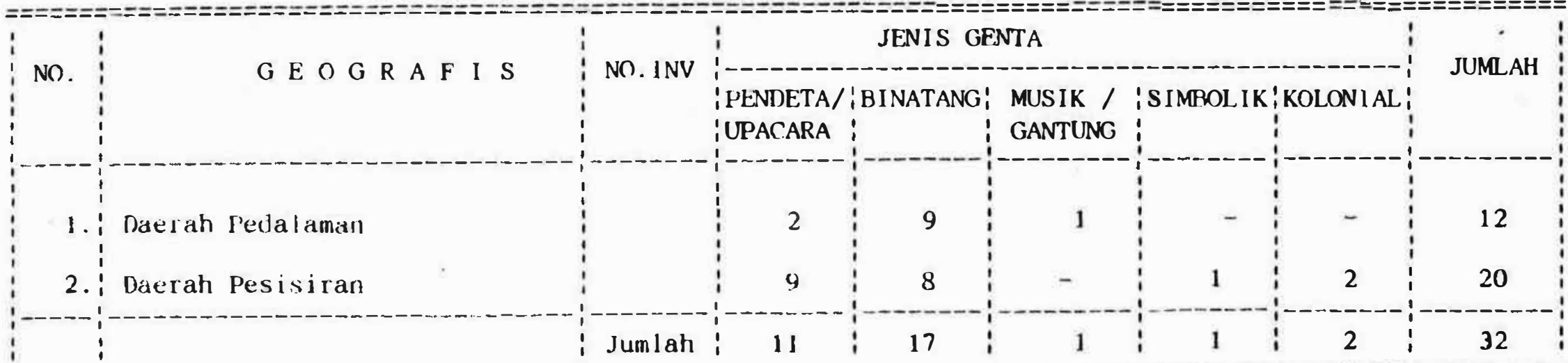




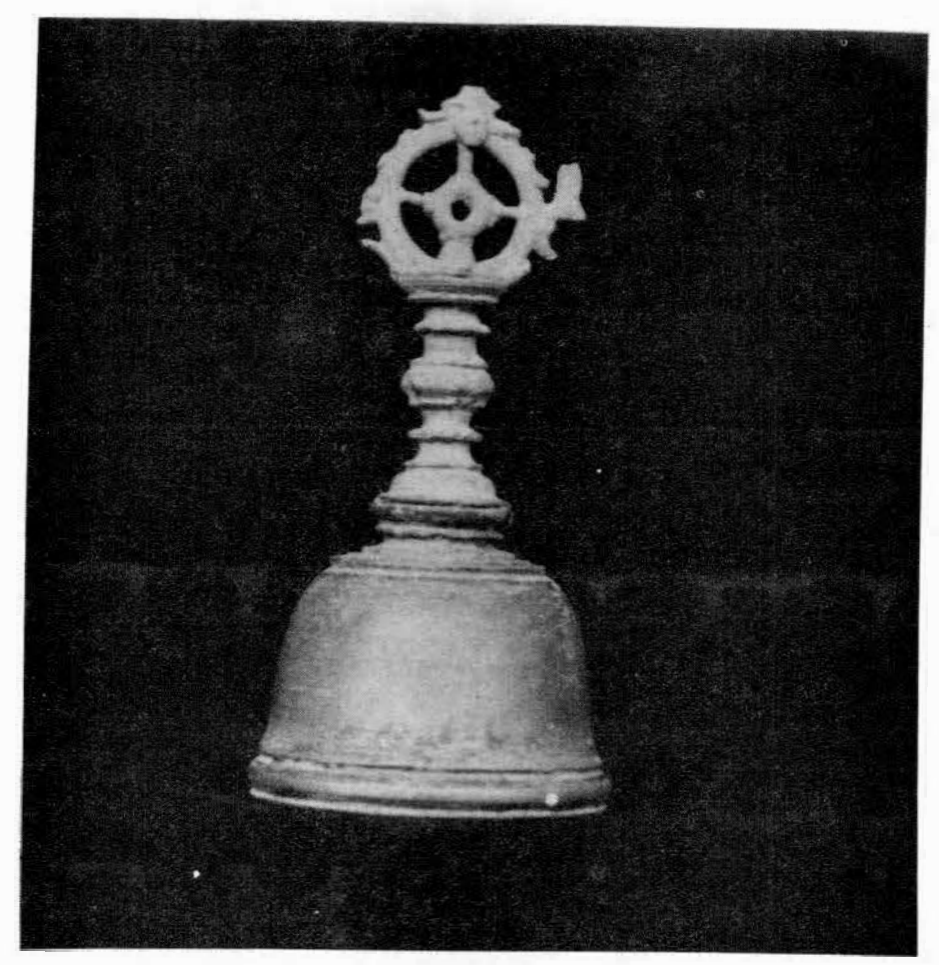

GENTA PENDETA / UPACARA

No. Inventaris : 4172

Asal : Desa Jurangjero, Kecamatan Jepon, Kabupaten Blora

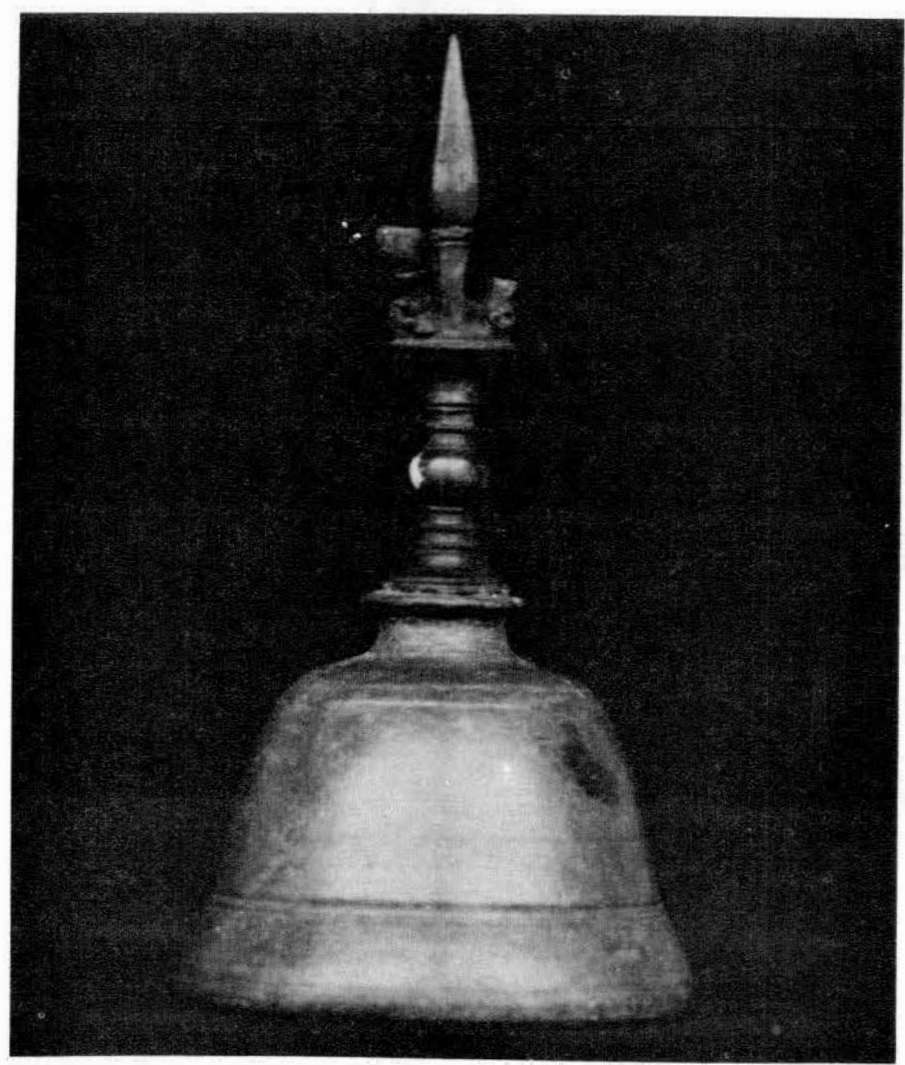

GENTA PENDETA / UPACARA

No. Inventaris : 3608

Asal : Desa Patemon, Kecamatan Gunung Pati, Kotamadia Semarang 


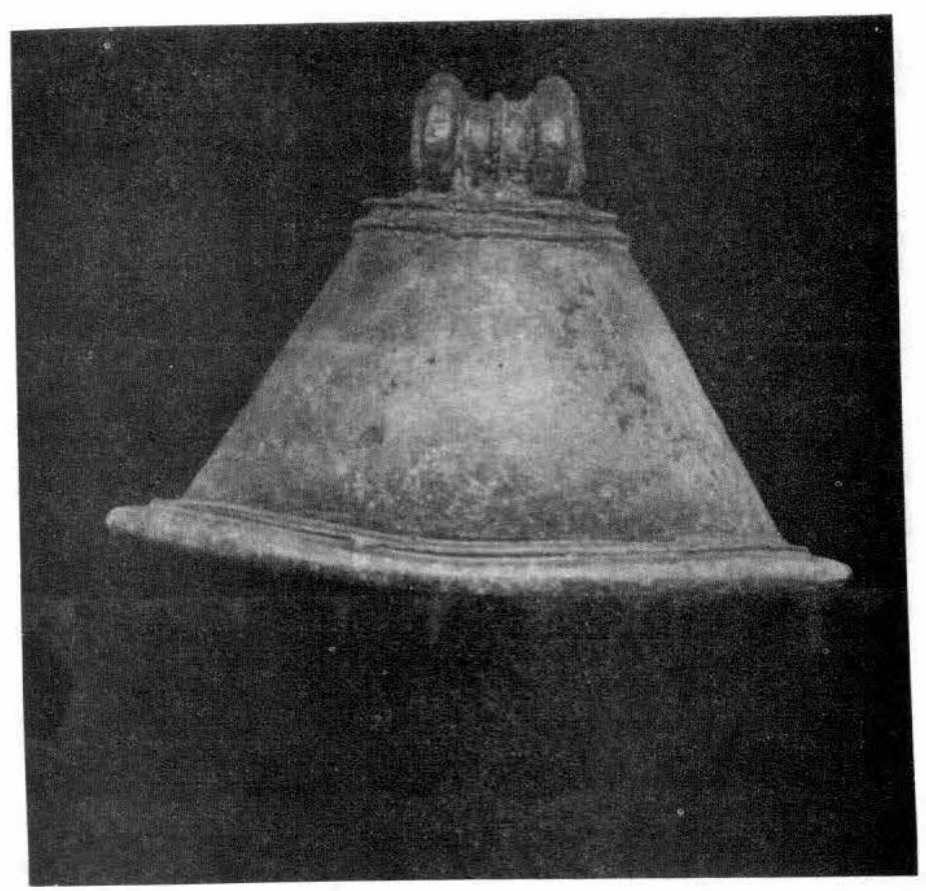

GENTA BINATANG

4

No. Inventaris : 2143

Asal: Desa Dragankampar, Kecamatan Musuk, Kabupaten Boyolali

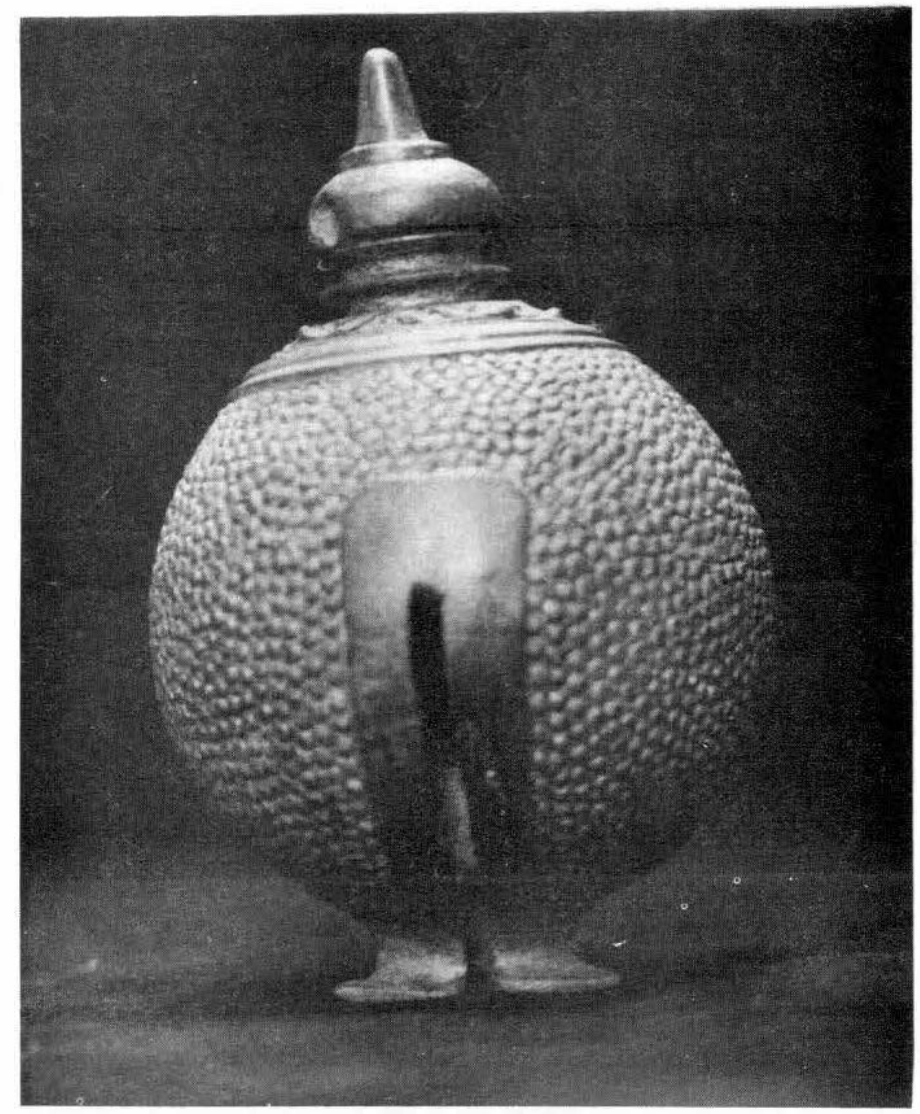

GENTA GANTUNG / MUSIK

No. Inventaris : E2. 2242

Asal : Kabupaten Cilacap 


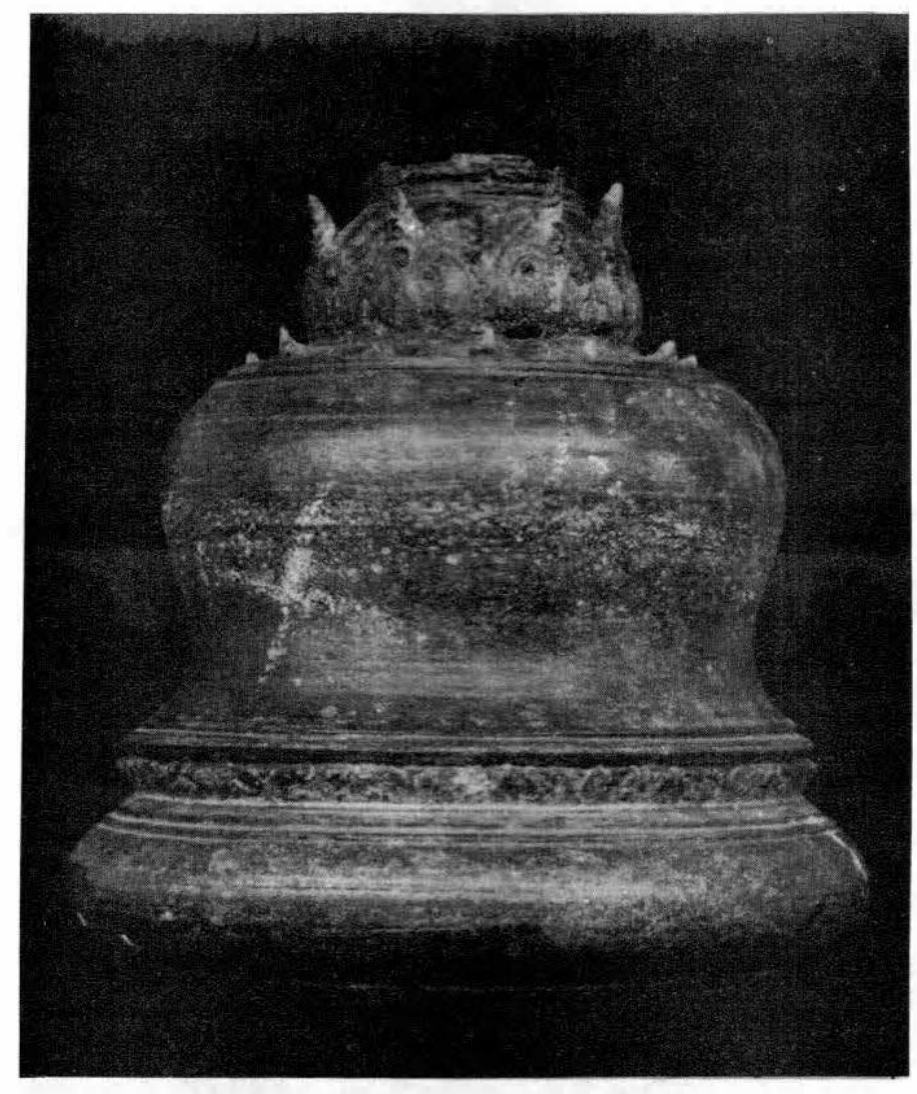

GENTA SIMBOLIK

No. Inventaris : 3942

Asal : Desa Cisumur, Kecamatan Gandrungmangu, Kabupaten Cilacap

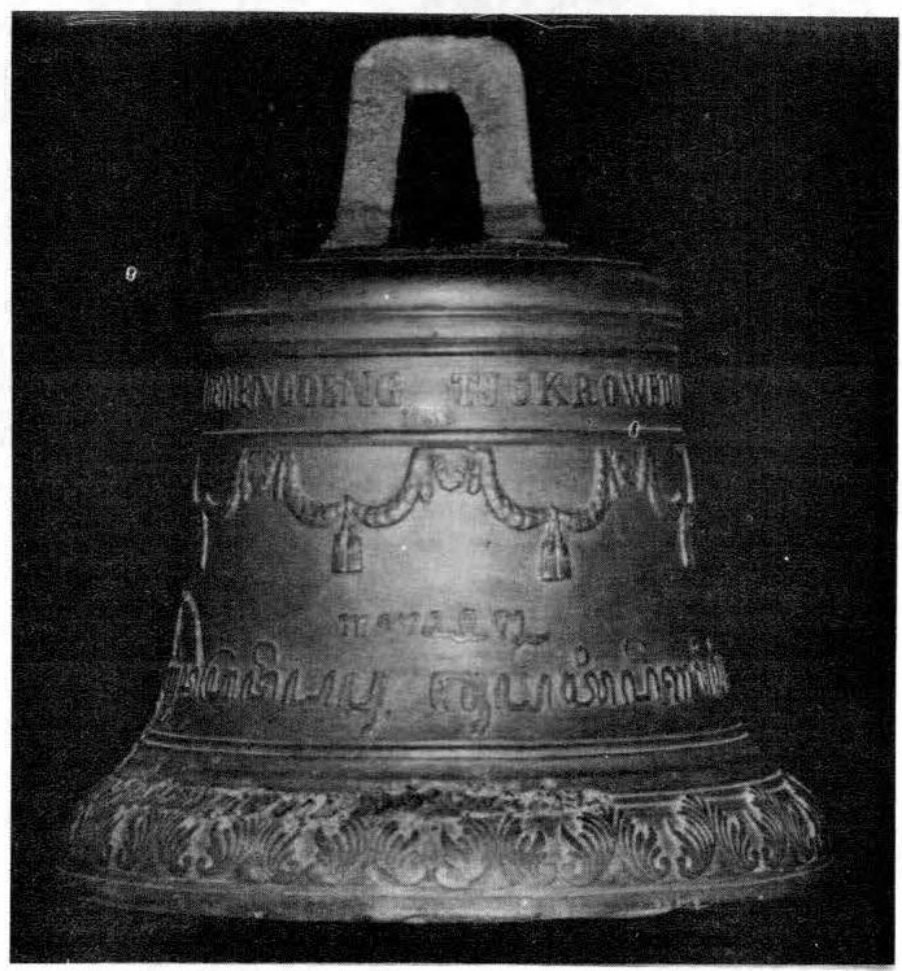

GENTA KOLONIAL.

No. Inventaris

Asal : Kabupaten Cilacap 


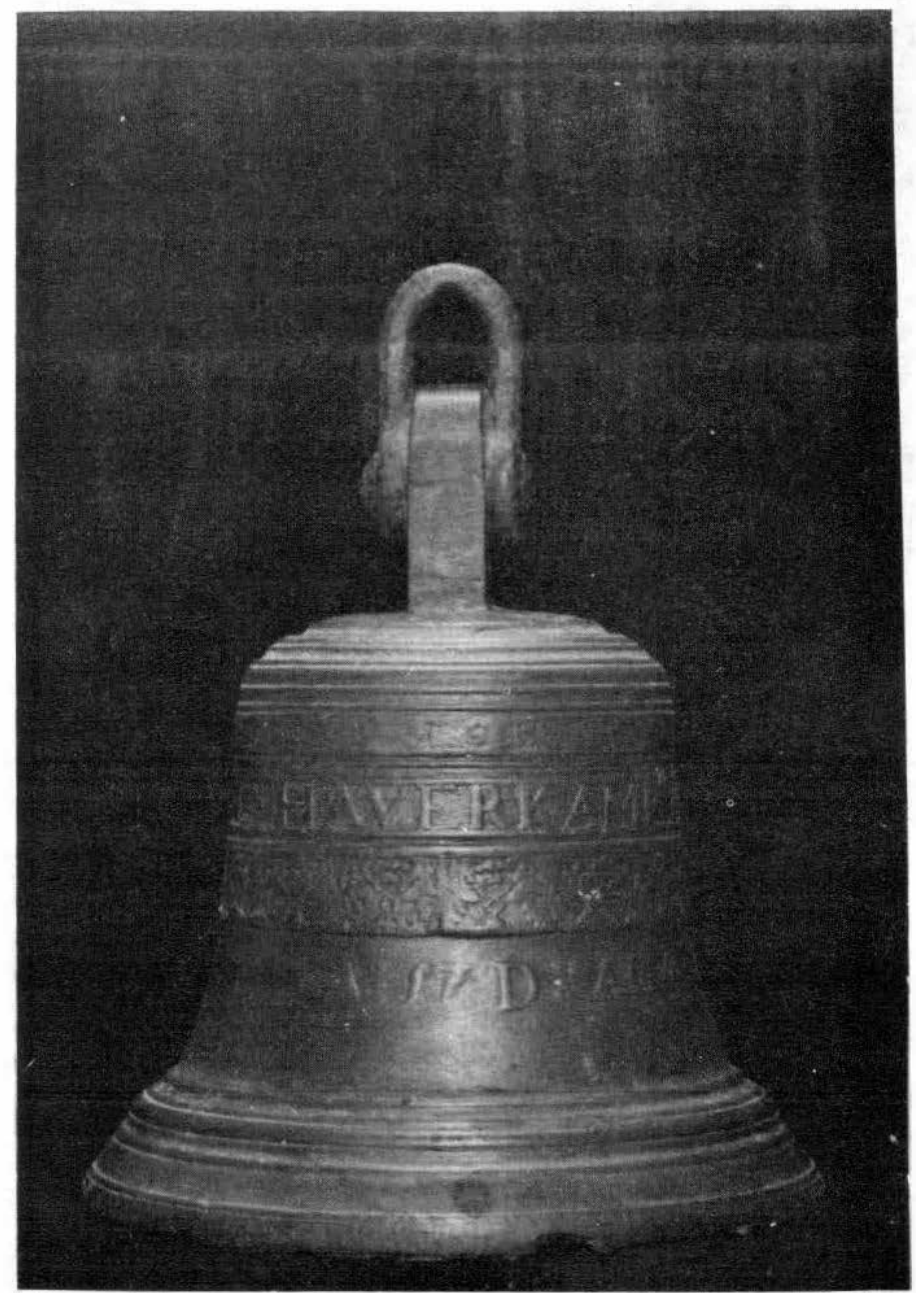

$+$

"ह

8

GENTA KOLONIAL

Asal : Kotamadia Tegal

i 